Т. А. Вакалюк // Актуальні питання сучасної педагогіки. Матеріали міжнародної науковопрактичної конференції (м. Острог, 1-2 листопада 2013 року). - Херсон : Видавничий дім «Гельветика», 2013. - С.97-99. 2. КМДА і Microsoft підписали угоду про впровадження інноваційних технологій [Електронний ресурс]. - Режим доступу : http:// economics.unian.ua/ transport/732520-kmda-i-microsoft-pidpisali-ugodu-pro-vprova djennya- innovatsiynihtehnologiy.html. - Назва 3 екрану. 3. Що таке хмарні обчислення або хмарні технології? [Електронний ресурс]. - Режим доступу: URL : http://programming. in.ua/otherfiles/internet/100-cloud-technologics.html. - Назва з екрану. 4. Vakaliuk T. Creating presentations for cloud services / Tetiana Vakaliuk// Journal L’Association 1901 «SEPIKE». - Osthofen, Deutschland. - Poitiers, France. - Los Angeles, USA. - Edition 05. - 2014. - P. 84-88. 5. Microsoft Office 365 [Електронний ресурс]. - Режим доступу: http://uk.wikipedia.org/wiki/ Microsoft_ Office_365. 6. Prezi [Електронний ресурс]. - Режим доступу : URL : http:// prezi.com/.

УДК 373.55.016:51(043.3)

Ніна Тарасенкова, Ірина Лов’янова

\title{
ПОБУДОВА СИСТЕМИ ЗМІСТУ НАВЧАННЯ МАТЕМАТИКИ У ПРОФІЛЬНІЙ ШКОЛІ З ПОЗИЦІЙ ПРОФЕСІЙНОЇ СПРЯМОВАНОСТІ НАВЧАННЯ
}

Тарасенкова Н. А., Лов’янова І. В. Побудова системи змісту навчання математики у профільній школі з позицій професійної спрямованості навчання.

У статті проаналізовано трактування поняття «зміст освіти», загальнотеоретичні підходи до структурування змісту шкільної освіти, вивчено принципи відбору змісту. На основі аналізу визначено фактори впливу на формування змісту шкільної математики і схарактеризовано компоненти змісту професійно спрямованого навчання математики.

Ключові слова: зміст освіти, принципи відбору змісту, компоненти змісту, професійно спрямоване навчання.

Тарасенкова Н. А., Ловьянова И. В. Построение системы содержания обучения математике в профильной школе с позиций профессиональной направленности обучения.

В статье проанализированы трактовки понятия «содержание образования», общетеоретические подходы к структурированию содержания школьного образования, изучены принципы отбора содержания. На основе анализа определены факторы влияния на формирование содержания школьной математики и охарактеризованы компоненты содержания профессионально направленного обучения математике.

Ключевые слова: содержание образования, принципы отбора содержания, компоненты содержания, профессионально направленное обучение.

Tarasenkova N. A., Lovyanova I. V. Formation of the teaching content of Mathematics at the profile school with professionally oriented training.

The article analyzes the meaning of the concept «content of education», theoretical approaches to structuring the content of school education and examins the principles of the content selection. On the basis of the analysis factors which influence the content formation of school Mathematics are defined and components of the content of professionally oriented training of Mathematics are characterized. 
Key words: the contentof education, the principles of selection, the content components, the professionally oriented training.

Зміст математичної освіти - це система в методичній системі професійно спрямованого навчання математики, яка вступає у тісний двобічний зв'язок з системою цілей i здійснює вплив на інші компоненти методичної системи. Аналізуючи зміст математичної освіти з позицій власного дослідження, прослідкуємо, як поняття зміст освіти потрактовано в педагогічній літературі, аналіз представлено у таблиці 1.

Аналіз пропонованих трактувань свідчить, що основними елементами змісту освіти $€$ знання і досвід способів діяльності, який своєю чергою поділяється на: когнітивний досвід особистості, досвід практичної діяльності, досвід творчості і досвід стосунків особистості.

Загальнотеоретичні основи структурування змісту шкільної освіти подано в працях В. Краєвського [5], В. Ледньова [6], М. Скаткіна [9].

Таблиця 1

Підходи до трактування поняття «зміст освіти»

\begin{tabular}{|c|c|}
\hline Автор & Трактування поняття «зміст освіти» \\
\hline $\begin{array}{l}\text { Педагогічний } \\
\text { енциклопедичний } \\
\text { словник [7, с. 266] }\end{array}$ & $\begin{array}{l}\text { Педагогічно адаптована система знань, умінь і навичок, досвіду } \\
\text { творчої діяльності та емоційно-ціннісного ставлення до світу, } \\
\text { засвоєння якої забезпечує розвиток особистості }\end{array}$ \\
\hline В. Сітаров [8] & $\begin{array}{l}\text { Система філософських і наукових знань, а також пов’язаних з ними } \\
\text { способів діяльності й відношень, поданих у навчальних предметах }\end{array}$ \\
\hline $\begin{array}{l}\text { М. Данілов, } \\
\text { В. Онищук [4] }\end{array}$ & $\begin{array}{l}\text { Система знань, умінь і навичок, що їх мають засвоїти учні, а також } \\
\text { досвід творчої діяльності та емоційно-вольового ставлення до світу }\end{array}$ \\
\hline В. Ледньов [6, с. 8] & $\begin{array}{l}\text { Зміст освіти визначається двома основними факторами: структурою } \\
\text { діяльності людини та структурою сукупного об’єкта вивчення }\end{array}$ \\
\hline $\begin{array}{l}\text { М. Скаткін, } \\
\text { В. Краєвський [9] }\end{array}$ & $\begin{array}{l}\text { Педагогічно адаптований соціальний досвід людства, тотожний за } \\
\text { своєю структурою людській культурі }\end{array}$ \\
\hline А. Хуторський [10] & $\begin{array}{l}\text { Освітнє середовище, здатне викликати особистісний освітній рух } \\
\text { учня і його внутрішнє зростання }\end{array}$ \\
\hline
\end{tabular}

Так, В. Краєвським [5] визначено три основні концепції формування змісту освіти: 1) сцієнтична концепція, в їі основі абсолютизація ролі науки у формуванні культури людини; 2) холістична концепція виходить з припущення, що сукупність знань, умінь і навичок необхідна для формування i розвитку різносторонньої особистості; 3) культурологічна концепція презентує зміст освіти як педагогічно адаптований соціальний досвід людства, тотожний культурі людства в усій структурній повноті.

Мета статmі- на основі пропонованих трактувань поняття «зміст освіти», загальнотеоретичних підходів до структурування змісту шкільної освіти та принципів відбору змісту визначити фактори впливу на формування змісту шкільної математики і схарактеризувати компоненти змісту професійно спрямованого навчання математики.

Зміст освіти є ширшим поняттям порівняно зі змістом навчання. Що стосується побудови змісту освіти на рівні навчального предмета, то, як зазначає С. Гончаренко [3, с. 17], методика орієнтується на його провідний компонент. У змісті навчального предмета має бути реалізоване методологічне положення про єдність змістового i процесуального аспектів у навчанні через опис понять складу і структури навчального 
предмета в термінах змісту й процесу.

У більшості трактувань основними структурними складниками змісту навчання постають знання, уміння та навички. Ці складники у структурі змісту представлені в певних ієрархіях: 1) від знань - до вмінь і від деяких із них - до навичок (Г. Костюк, О. Савченко, С. Гончаренко); 2) від знань - до первинних умінь, а від них - до навичок і вторинних умінь (В. Артемов, А. Богуш, П. Гальперін); 3) від знань - до навичок, а від них - до вмінь (С. Рубінштейн, І. Лернер, О. Онищук). Вибір однієї з ієрархій залежить від специфічних особливостей змісту навчання конкретного предмета, зокрема вивченню математики відповідає ієрархія під номером три.

Втіленням концептуальних задумів профільного навчання у зміст освіти є профільне наповнення змісту, яке на сьогодні досягається за рахунок виділення трьох рівнів: академічного, профільного і стандартного. Проте зміст навчання шкільного предмета також можна формувати виходячи із структури профільного навчання, а саме: базовий зміст, профільний зміст, зміст курсів за вибором. Якщо перший підхід визначення трьох рівнів у змісті відповідає рівням математичної підготовки у профільній школі, то використання другого підходу до формування змісту наближає цей процес до дворівневої структури «базовий рівень - профільний рівень», яка зараз активно обговорюється в межах формування оновленої концепції профільної школи.

Вичерпна характеристика змісту навчання передбачає визначення: системи принципів побудови змісту навчання; факторів формування змісту; системи компонентів змісту; способів пред’явлення змісту.

Принципи відбору й побудови змісту навчання за М. Бурдою [2] наведено й систематизовано у таблиці 2.

Таблиця 2

Принципи відбору змісту за М. Бурдою [2]

\begin{tabular}{|c|c|}
\hline Принцип & Зміст принципу \\
\hline соціальна ефективність & $\begin{array}{l}\text { математичні знання мають бути достатніми для продовження } \\
\text { освіти або кваліфікованої праці }\end{array}$ \\
\hline $\begin{array}{l}\text { пріоритет розвивальної } \\
\text { функції }\end{array}$ & $\begin{array}{l}\text { 3міст навчального матеріалу має забезпечувати не екстенсивне, } \\
\text { iнтенсивне навчання і самонавчання учнів, засвоєння не лише } \\
\text { готових знань, а й способів цього засвоєння, способів міркувань } \\
\text { які застосовуються в математиці }\end{array}$ \\
\hline $\begin{array}{l}\text { диференційована } \\
\text { реалізованість }\end{array}$ & $\begin{array}{l}\text { зміст математики розрахований на здійснення основних видів } \\
\text { диференціації - за змістом навчального матеріалу, за рівнями } \\
\text { вимог до математичної підготовки учнів }\end{array}$ \\
\hline $\begin{array}{l}\text { науковість і прикладна } \\
\text { реалізованість }\end{array}$ & \begin{tabular}{|llll} 
поєднання неперервної і дискретної математики, розкриття \\
гносеологічного її значення
\end{tabular} \\
\hline модульний принцип & $\begin{array}{l}\text { курс математики передбачає дві частини - інваріантну і варіативну, } \\
\text { остання містить логічно } \quad \text { завершені } \quad \text { порції } \\
\text { доповнеріалу, які }\end{array}$ \\
\hline принцип фузіонізму & $\begin{array}{l}\text { iнтеграція змісту досягається введенням узагальнюючих понять } \\
\text { сучасної математики; посилення зв’язків між алгеброю і } \\
\text { геометрією, планіметрією і стереометрією }\end{array}$ \\
\hline принцип концентризму & $\begin{array}{l}\text { математична підготовка школярів досягається концентричним } \\
\text { розвитком таких груп знань: 1) числа і дії над ними, величини, }\end{array}$ \\
\hline
\end{tabular}




\begin{tabular}{|c|c|}
\hline Принцип & Зміст принципу \\
\hline & $\begin{array}{l}\text { метрична система мір; 2) вирази, рівняння, нерівності, елементи } \\
\text { логіки; 3) функції, дослідження функцій методами математичногф } \\
\text { аналізу; 4) геометричні фігури та їх властивості, геометричні } \\
\text { величини, перетворення фігур; } 5 \text { 5оорднати і вектори; } \\
\text { 6) комбінаторика; 7) елементи статистики і теорії ймовірностей; } \\
\text { 8) математика і зовнішній світ: моделювання, аналіз даних, } \\
\text { специфіка математики як науки, математика в системі наук, історія } \\
\text { виникнення і розвитку математичних теорій }\end{array}$ \\
\hline
\end{tabular}

Визначаючи чинники, які впливають на формування змісту шкільної математики, ми дотримуємося точки зору М. Бурди [1], який виокремлює такі:

- значення математичної освіти для життєдіяльності особистості;

- урахування соціальних потреб суспільства і цілей, які воно ставить перед навчанням математики;

- відображення компонентів математичної науки у шкільних підручниках;

- урахування основних видів діяльності людини, структури й особливостей цієї діяльності.

У профільній підготовці старшокласників професійна спрямованість навчання передбачає формування стійких мотивів вивчення шкільних дисциплін, які для цього напряму підготовки не є профільними; організацію засвоєння знань і досвіду діяльності 3 позиції ціннісних орієнтацій старшокласників, формування професійно важливих якостей особистості та якісну математичну підготовку учнів у межах обраного навчального профілю.

До системи компонентів змісту професійно спрямованого навчання математики ми відносимо такі:

- предметний - це базовий зміст навчальної дисципліни, що забезпечує рівень знань, визначений державним стандартом, складається з певної наукової інформації, що активізує пізнавальні потреби і впливає на розвиток пізнавальних інтересів особистості, відповідає віковим особливостям учнів, а також кількості часу, який надається на його вивчення;

- діяльнісний - це передбачувані у змісті навчання математики види діяльності (загальнонавчальна, пізнавальна, перетворювальна, самоорганізуюча), характерні для відповідної науки і сфери діяльності людини, які дозволяють перехід від засвоєння дійсності до внутрішнього особистісного зростання, а потім до опанування культурноісторичних досягнень;

- когнітивно-семіотичний - спрямованість змісту на розвиток рефлексивної мислительної діяльності учнів у процесі пізнання та перетворення системи знаковосимволічних засобів;

- компетентнісний - реалізація у змісті груп компетентностей, які передбачають зміни соціальної діяльності особистості, пов’язані із внутрішньою мотивацією, інтересами та сферою знань;

- аксіологічний - орієнтація змісту на розкриття ціннісно-цільових приорітетів навчально-пізнавальної діяльності.

Визначення такої групи компонентів змісту навчання математики здійснювалося нами на психологічних, дидактичних і методичних підставах, а саме:

1) зміст навчання має ураховувати психологічні потреби особистості в пізнанні, 
практичній діяльності, в пошуковій і творчій активності, в емоційній насиченості буття, у визнанні іншими людьми й спілкуванні 3 ними, а також відповідні до цих потреб інтелектуальні здібності людини;

2) зміст навчання будується відповідно до комплексу дидактичних цілей;

3) види навчальної діяльності, закладені у змісті, спрямовуються на набуття досвіду в пізнавальній, практичній, творчо-пошуковій, ціннісно-смисловій, комунікативній діяльності учнів.

Виокремлені компоненти змісту розгортаються концентрично (уточнюються, поглиблюються й узагальнюються) протягом всього вивчення математики у старшій школі.

Підсумовуючи, варто наголосити на тому, що компонентна побудова змісту навчання математики передусім передбачає формування стійких систематизованих знань основ науки, вияв переваг предметної структури навчання, створення оптимальних умов освіти, виховання i розвитку особистості учнів в напрямку професійної спрямованості і в перспективі має набути фіксації в навчальних планах і програмах та, відповідно, бути відображеною у змісті шкільних підручників.

\section{Література}

1. Бурда М. Гуманістична орієнтація змісту підручників з математики / Михайло Бурда // Підготовка майбутнього вчителя природничих дисциплін в умовах моделювання освітнього середовища: [збірник укладено за матер. міжнародної науково-практичної конференції] / кол. авт. - Полтава : АСМI, 2004. - С. 55-58. 2. Бурда М. І. Зміст шкільної математичної освіти як предмет методичного дослідження / М. І. Бурда // Педагогічні засади формування гуманістичних цінностей природничої освіти, її спрямованість на розвиток особистості: [збірник матеріалів міжнародної науково-практичної конференції]. - Полтава : ACMI, 2003. - С. 15-16. 3. Гончаренко С. У. Методика як наука / С. У. Гончаренко. Хмельницький : Вид-во ХГПК, 2000. - 30 с. 4. Дидактика современной школы: [пособие для учителей] / Б. С. Кобзарь, Г. Ф. Кумарина, Ю. А. Кусый и др.; под ред. В. А. Онищука. - Київ : Рад. шк., 1987. - 351 с. 5. Краевский В. В. Проблемы научного обоснования обучения / В. В. Краевский. - Москва : Педагогика, 1977. - 264 с. 6. Леднев В. С. Содержание образования / В. С. Леднев. - Москва : Высшая школа, 1989. - 360 с. 7. Педагогический энциклопедический словарь / гл. ред. Б. М. Бим-Бад / ред. кол. М. М. Безруких, В. А. Болотов, Л. С. Глебова и др. - Москва : Большая Российская энциклопедия. - 2003. - 528 с. 8. Ситаров В. А. Дидактика: [учебное пособие для студ. высш. пед. учеб. заведений] / В. А. Ситаров; под ред. В. И. Сластенина. - Москва : Издательский центр «Академия», 2002. 368 с. 9. Скаткин М. Н. Содержание общего среднего образования : Проблемы и перспективы / М. Н. Скаткин, $\quad$ В. В. Краевский. - Москва : Знание, $1981 .-96$ с. 10. Хуторской А. В. Современная дидактика : [ученик для вузов] / Андрей Викторович Хуторской. - Санкт-Петербург : Питер, 2001. - 544 с.

УДК 37.015.31:78

Ірина Могілей

\section{ШЛЯХИ ФОРМУВАННЯ ДУХОВНИХ ПОТРЕБ УЧНІВ СЕРЕДНІХ КЛАСІВ ЗАСОБАМИ КОМПЛЕКСУ МИСТЕЦТВ НА УРОКАХ МУЗИЧНОГО МИСТЕЦТВА}

Могілей І. В. Шляхи формування духовних потреб учнів середніх класів засобами комплексу мистецтв на уроках музичного мистецтва. 